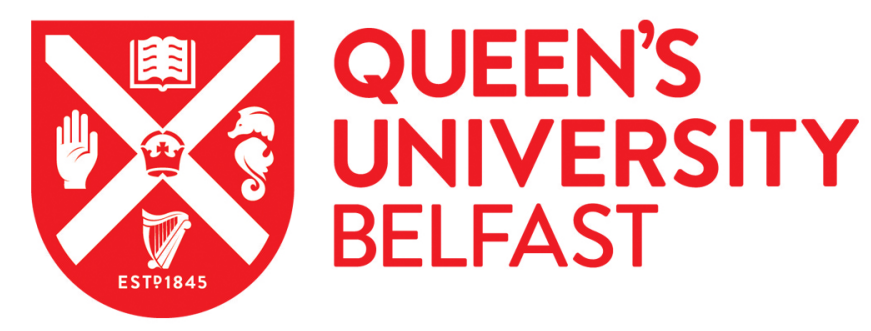

\title{
Seasonal temperatures have more influence than nitrogen fertilizer rates on cucumber yield and nitrogen uptake in a double cropping system
}

Guo, R. Y., Li, X. L., Christie, P., Chen, Q., \& Zhang, F. S. (2008). Seasonal temperatures have more influence than nitrogen fertilizer rates on cucumber yield and nitrogen uptake in a double cropping system. Environmental Pollution, 151(3), 443-451. https://doi.org/10.1016/j.envpol.2007.04.008

\section{Published in:}

Environmental Pollution

Queen's University Belfast - Research Portal:

Link to publication record in Queen's University Belfast Research Portal

\section{General rights}

Copyright for the publications made accessible via the Queen's University Belfast Research Portal is retained by the author(s) and / or other copyright owners and it is a condition of accessing these publications that users recognise and abide by the legal requirements associated with these rights.

Take down policy

The Research Portal is Queen's institutional repository that provides access to Queen's research output. Every effort has been made to ensure that content in the Research Portal does not infringe any person's rights, or applicable UK laws. If you discover content in the Research Portal that you believe breaches copyright or violates any law, please contact openaccess@qub.ac.uk. 


\title{
Seasonal temperatures have more influence than nitrogen fertilizer rates on cucumber yield and nitrogen uptake in a double cropping system
}

\author{
Ruiying Guo ${ }^{\text {a }}$, Xiaolin $\mathrm{Li}^{\text {a }}$, Peter Christie ${ }^{\mathrm{a}, \mathrm{b}}$, Qing Chen ${ }^{\mathrm{a}, *}$, Fusuo Zhang ${ }^{\mathrm{a}}$ \\ ${ }^{a}$ College of Resources and Environmental Sciences, China Agricultural University, No. 2 Yuanmingyuan Xilu, Haidian District, Beijing 100094, China \\ ${ }^{\mathrm{b}}$ Agricultural and Environmental Science Department, Queen's University Belfast, Belfast BT9 5PX, UK
}

Received 2 October 2006; received in revised form 25 March 2007; accepted 16 April 2007

Nitrogen inputs can be reduced to minimize $N$ losses to the environment while maintaining yields but $N$ recommendations must reflect seasonal temperature effects.

\begin{abstract}
Two-year greenhouse cucumber experiments were conducted to investigate seasonal effects on fruit yield, dry matter allocation, and $\mathrm{N}$ uptake in a double-cropping system with different fertilizer management. Seasonal effects were much greater than fertilizer effects, and winter-spring (WS) cucumber attained higher fruit yields and $\mathrm{N}$ uptake than autumn-winter (AW) cucumber due to lower cumulative air temperatures during fruit maturation in the AW season. Fertilizer $\mathrm{N}$ application and apparent $\mathrm{N}$ loss under recommended $\mathrm{N}$ management (Nmr) decreased by 40-78\% and 33-48\% without yield loss compared to conventional $\mathrm{N}$ management (Nmt) over four growing seasons. However, there were no seasonal differences in $\mathrm{N}$ recommendations, taking into consideration seasonal differences in crop $\mathrm{N}$ demand, critical nutrient supply in the root zone and $\mathrm{N}$ mineralization rate.
\end{abstract}

(C) 2007 Elsevier Ltd. All rights reserved.

Keywords: Seasonal differences; Greenhouse cucumber; N recommendations; N loss

\section{Introduction}

Recent investigations on common fertilizer practices in the North China Plain have revealed excessive $\mathrm{N}$ fertilizer applications in intensive vegetable production systems, with fertilizer $\mathrm{N}$ application rates ranging from 500 to $1900 \mathrm{~kg} \mathrm{~N} \mathrm{ha}^{-1}$ per season in greenhouse cropping systems (Chen et al., 2004; Zhang et al., 1996). It was comparable with $\mathrm{N}$ fertilization in Valencian Community region areas with intensive agricultural production in Spain, in which nitrogen fertilization in pepper and tomato cropping system could reach to 1030 and $940 \mathrm{~kg} \mathrm{~N} \mathrm{ha}^{-1}$, respectively (Ramos et al., 2002). Fertilizer $\mathrm{N}$ use efficiency in

\footnotetext{
* Corresponding author. Tel.: +86106273 3822; fax: +86 1062731016 . E-mail address: qchen@cau.edu.cn (Q. Chen).
}

intensively managed greenhouse vegetable systems can be less than $10 \%$ using conventional management practices (Zhu et al., 2005), consequently large amounts of unused nitrogen are released to the environment through nitrate leaching, denitrification and $\mathrm{NH}_{3}$ volatilization (Cabrera et al., 1993; Cabrera and Chiang, 1994; Fox et al., 1996; Gollany et al., 2004; Ramos et al., 2002). For example, nitrate- $\mathrm{N}$ concentrations in shallow wells around greenhouses in Huimin, Shandong, ranged from 9 to $274 \mathrm{mg} \mathrm{N} \mathrm{L}^{-1}$, with $99 \%$ of surveyed wells exceeding the USEPA limit of $10 \mathrm{mg} \mathrm{N} \mathrm{L}^{-1}$, more than half of the samples (53\%) exceeding $50 \mathrm{mg} \mathrm{N} \mathrm{L}^{-1}$, and $26 \%$ exceeding $100 \mathrm{mg} \mathrm{N} \mathrm{L}^{-1}$ (Ju et al., 2006).

Double-cropping systems are typical in greenhouse planting systems without supplementary heating or illumination on the North China Plain. The convention is to plant one species of vegetable in the WS season from February to June and the 
AW season from September to the following January. The summer season is usually fallow because of the hot weather. Seasonal patterns in cucumber yield formation have been studied (Pei, 2002) and yield differences in greenhouse fruit vegetables between the WS $\left(80-120 \mathrm{tha}^{-1}\right)$ and AW $\left(30-60 \mathrm{tha}^{-1}\right)$ seasons are well known on the North China Plain. Conventional N management comprises basal $\mathrm{N}$ fertilization before transplanting followed by $6-10$ split side-dressing events with irrigation. This regime seldom takes into consideration the patterns of crop $\mathrm{N}$ demand and soil $\mathrm{N}$ supply and, not surprisingly, excessive $\mathrm{N}$ supply is difficult to avoid.

Integrated $\mathrm{N}$ management determines the critical $\mathrm{N}$ level in the root zone by determination of the $\mathrm{N}$ supply from the soil, environmental conditions, synthetic fertilizer applications and organic amendments and optimizes nutrient and water supplies in space and time in the root environment. Practical $\mathrm{N}$ recommendation strategies, such as the PSNT technique (Breschini and Hartz, 2002; Hartz et al., 2000; Heckman et al., 2002; Krusekopf et al., 2002), the N-EXPERT system (Fink and Scharpf, 1993) and the target value for $\mathrm{N}$ recommendations (He et al., 2007) have been used to maintain optimum soil $\mathrm{N}_{\text {min }}$ levels in the effective root zone for sustainable vegetable production. Different seasonal patterns of vegetable $\mathrm{N}$ uptake are regarded as an important parameter for balanced $\mathrm{N}$ recommendations and this also increases the complexity involved in calculating a suitable $\mathrm{N}$ supply in the root zone as influenced by variation in seasonal temperatures.

It is therefore important to understand the seasonal influences on the changing dynamics of $\mathrm{N}$ uptake and yield formation in greenhouse vegetables such as cucumber at different growth stages, especially in double-cropping systems with different fertilizer practices on the North China Plain.

\section{Materials and methods}

\subsection{Experimental site}

Field experiments were conducted in a typical double-cropping greenhouse planting system in Changping county, Beijing suburbs from 2005 to 2006. A typical five-year commercial greenhouse covered with plastic film (ground area $6 \mathrm{~m} \times 72 \mathrm{~m}$ ) was randomly selected for the experiments without supplementary lighting or heating.

The surface soil in the greenhouse $(0-30 \mathrm{~cm}$ layer) had a silt loamy texture, a $\mathrm{pH}$ (in water) of 6.1 , an electrical conductivity (EC) value of $214 \mu \mathrm{s} \mathrm{cm}^{-1}$, a density of $1370 \mathrm{~kg} \mathrm{~m}^{-3}$, an initial soil $\mathrm{N}_{\min }$ of $255 \mathrm{~kg} \mathrm{~N} \mathrm{ha}^{-1}$ and an organic matter content of $24.0 \mathrm{~g} \mathrm{~kg}^{-1}$ prior to the experiments. Total $\mathrm{N}$, Olsen-P and $\mathrm{NH}_{4} \mathrm{OAc}-\mathrm{K}$ were $1.78 \mathrm{~g} \mathrm{~kg}^{-1}, 305$ and $470 \mathrm{mg} \mathrm{kg}^{-1}$, respectively. Groundwater that is also used as a source of drinking water was used for irrigation (nitrate content $0.44 \mathrm{mg} \mathrm{L}^{-1}$ ).

\subsection{Crop establishment and management}

Cucumber seedlings (Cucumis sativus L. cv. Jinglu No. 3) with two leaves were transplanted by hand in double rows with $0.9 \mathrm{~m}$ row spacing and $0.3 \mathrm{~m}$ seedling spacing. Four successive growing seasons were investigated. The seedlings were transplanted on 11 March 2005 and the vines were removed on 21 June 2005 in the first season (2005 WS season); after the summer fallow a second crop using the same cultivar was grown from 8 September 2005 to 7 January 2006 (2005 AW season). The third and final cucumber crops (both cv. Zhongte No. 25) grew from 15 February 2006 to 18 June 2006 (2006 WS season) and from 10 September 2006 to 30 November 2006 (2006 AW season), respectively.
Weeds were controlled by hand. Fungicide sprays were used to control powdery mildew and downy mildew which frequently occurred during cucumber growth. Other aspects of crop management followed conventional practices. Harvesting of cucumber fruits grown during the four cropping seasons started on 21 April 2005, 18 October 2005, 9 April 2006 and 9 October 2006, respectively. Commercial fruits $(2.5-3.0 \mathrm{~cm}$ in diameter and $25-30 \mathrm{~cm}$ long) were picked following conventional harvesting practice and weighed from 24 plants in each plot. Cucumber vines were removed from the greenhouse after the final fruit harvest of each crop to minimize the risk of fungal disease.

\subsection{Experimental treatments}

Four treatments were set up as follows:

(1) Control treatment (NO0): neither organic manure nor chemical fertilizer $\mathrm{N}$ was applied.

(2) Organic manure treatment $(\mathrm{Nm} 0)$ : only organic manure was broadcast as a basal fertilizer and no chemical $\mathrm{N}$ fertilizer was applied. 75, 22.5, 11 and $18 \mathrm{tha}^{-1}$ of chicken manure (representing total $\mathrm{N}$ inputs of 671, 200, 146 and $205 \mathrm{~kg} \mathrm{~N} \mathrm{ha}^{-1}$ ) were broadcast before transplanting in the four growing seasons, respectively. Organic matter, total $\mathrm{P}$ and total $\mathrm{K}$ contents of the organic manure used in 2006 were $30.9 \%, 12.6 \mathrm{~g} \mathrm{~kg}^{-1}\left(\mathrm{P}_{2} \mathrm{O}_{5}\right)$ and $2.45 \mathrm{~g} \mathrm{~kg}^{-1}\left(\mathrm{~K}_{2} \mathrm{O}\right)$, respectively.

(3) Conventional $\mathrm{N}$ management $(\mathrm{Nmt})$ : on the basis of the same application of chicken manure as in the $\mathrm{Nm} 0$ treatment, $\mathrm{N}$ fertilizer was topdressed following conventional methods (Tables 1 and 2) based on survey results from the region.

(4) Reduced-N management (Nmr): with the same application rate of chicken manure as in the $\mathrm{Nm} 0$ treatment, balanced $\mathrm{N}$ fertilization was based on a $\mathrm{N}$ target value (including soil $\mathrm{N}_{\min }$ safety margin and crop uptake) and soil $\mathrm{N}_{\min }$ in the root zone. The equation was as follows:

Recommended fertilizer $\mathrm{N}=\left[\right.$ Output $\left(\right.$ crop N uptake $+\operatorname{soil~}_{\text {min }}$ safety margin)] - [Input (soil $\mathrm{N}_{\min }$ in the root zone before side-dressing)]

Here, soil $\mathrm{N}_{\text {min }}$ safety margin refers to the critical residual soil $\mathrm{N}_{\min }$ in the root zone required to maintain crop growth (Tremblay et al., 2001), which was modified to $200 \mathrm{~kg} \mathrm{~N} \mathrm{ha}^{-1}$, referenced from soiless experiments using cucumber (Kotsiras et al., 2002). Seasonal N uptake by above-ground parts of cucumber was calculated based on the following formula (Pei, 2002) which describes cucumber growth with similar yield levels in the same county of the Beijing suburbs.

Table 1

$\mathrm{N}$ fertilizer application rates and irrigation rates in greenhouse cucumber experiment in 2005 at Changping, Beijing suburbs

\begin{tabular}{|c|c|c|c|c|c|c|c|}
\hline \multicolumn{4}{|c|}{$2005 \mathrm{WS}^{\mathrm{a}}$} & \multicolumn{4}{|c|}{2005 AW } \\
\hline \multirow[t]{2}{*}{ Date } & \multirow{2}{*}{$\begin{array}{l}\text { Irrigation } \\
\text { Rate } \\
(\mathrm{mm})\end{array}$} & \multicolumn{2}{|c|}{$\begin{array}{l}\mathrm{N} \text { application } \\
\text { rate }\left(\mathrm{kg} \mathrm{ha}^{-1}\right)\end{array}$} & \multirow[t]{2}{*}{ Date } & \multirow{2}{*}{$\begin{array}{l}\text { Irrigation } \\
\text { rate } \\
(\mathrm{mm})\end{array}$} & \multicolumn{2}{|c|}{$\begin{array}{l}\mathrm{N} \text { application } \\
\text { rate }\left(\mathrm{kg} \mathrm{ha}^{-1}\right)\end{array}$} \\
\hline & & $\mathrm{Nmt}^{\mathrm{b}}$ & $\mathrm{Nmr}$ & & & $\mathrm{Nmt}$ & $\mathrm{Nmr}$ \\
\hline $11 \mathrm{Mar}$ & 30 & 0 & 0 & $8 \mathrm{Sept}$ & 38 & 0 & 0 \\
\hline $16 \mathrm{Mar}$ & 35 & 0 & 0 & $20 \mathrm{Sept}$ & 30 & 0 & 0 \\
\hline $24 \mathrm{Mar}$ & 35 & 0 & 0 & 4 Oct & 41 & 0 & 0 \\
\hline $4 \mathrm{Apr}$ & 35 & 0 & 0 & 15 Oct & 22 & 0 & 0 \\
\hline $16 \mathrm{Apr}$ & 35 & 115 & 0 & 23 Oct & 36 & 87 & 98 \\
\hline $25 \mathrm{Apr}$ & 34 & 176 & 0 & $1 \mathrm{Nov}$ & 27 & 87 & 100 \\
\hline 6 May & 25 & 176 & 0 & $11 \mathrm{Nov}$ & 38 & 108 & 0 \\
\hline 14 May & 35 & 143 & 77 & $21 \mathrm{Nov}$ & 23 & 108 & 0 \\
\hline 25 May & 29 & 50 & 0 & $1 \mathrm{Dec}$ & 27 & 120 & 92 \\
\hline 1 Jun & 44 & 0 & 75 & $11 \mathrm{Dec}$ & 27 & 90 & 75 \\
\hline 11 Jun & 29 & 50 & 0 & $20 \mathrm{Dec}$ & 23 & 75 & 40 \\
\hline Sum & 367 & 710 & 152 & Sum & 330 & 675 & 405 \\
\hline
\end{tabular}

${ }^{\mathrm{a}} \mathrm{WS}$ and AW denote winter-spring season and autumn-winter season, respectively.

${ }^{\mathrm{b}} \mathrm{Nmt}$ and $\mathrm{Nmr}$ denote conventional $\mathrm{N}$ management and reduced $\mathrm{N}$ management, respectively. 
Table 2

$\mathrm{N}$ fertilizer application rates and irrigation rates in greenhouse cucumber experiment during the autumn-winter season in 2006 at Changping, Beijing suburbs

\begin{tabular}{|c|c|c|c|c|c|c|c|}
\hline \multicolumn{4}{|l|}{$06 \mathrm{WS}^{\mathrm{a}}$} & \multicolumn{4}{|l|}{$06 \mathrm{AW}$} \\
\hline \multirow[t]{2}{*}{ Date } & \multirow[t]{2}{*}{$\begin{array}{l}\text { Irrigation } \\
\text { Rate }(\mathrm{mm})\end{array}$} & \multicolumn{2}{|c|}{$\begin{array}{l}\mathrm{N} \text { application } \\
\text { rate }\left(\mathrm{kg} \mathrm{ha}^{-1}\right)\end{array}$} & \multirow[t]{2}{*}{ Date } & \multirow[t]{2}{*}{$\begin{array}{l}\text { Irrigation } \\
\text { rate }(\mathrm{mm})\end{array}$} & \multicolumn{2}{|c|}{$\begin{array}{l}\mathrm{N} \text { application } \\
\text { rate }\left(\mathrm{kg} \mathrm{ha}^{-1}\right)\end{array}$} \\
\hline & & $\mathrm{Nm}^{\mathrm{b}}$ & $\mathrm{Nmr}$ & & & $\mathrm{Nmt}$ & $\mathrm{Nmr}$ \\
\hline $15 \mathrm{Feb}$ & 17 & 0 & 0 & $10 \mathrm{Sept}$ & 25 & 0 & 0 \\
\hline $2 \mathrm{Mar}$ & 22 & 0 & 0 & $16 \mathrm{Sept}$ & 21 & 0 & 0 \\
\hline $11 \mathrm{Mar}$ & 17 & 0 & 0 & $23 \mathrm{Sept}$ & 22 & 0 & 0 \\
\hline 18 Mar & 19 & 0 & 0 & 1 Oct & 21 & 0 & 0 \\
\hline 27 Mar & 24 & 0 & 0 & $10 \mathrm{Oct}$ & 17 & 120 & 75 \\
\hline 7 Apr & 15 & 123 & 77 & 19 Oct & 16 & 0 & 0 \\
\hline $15 \mathrm{Apr}$ & 17 & 123 & 77 & $28 \mathrm{Oct}$ & 19 & 120 & 75 \\
\hline $21 \mathrm{Apr}$ & 12 & 0 & 0 & $9 \mathrm{Nov}$ & 18 & 100 & 50 \\
\hline $29 \mathrm{Apr}$ & 12 & 0 & 0 & 18 Nov & 17 & 100 & 50 \\
\hline 7 May & 14 & 84 & 46 & $2 \mathrm{Dec}$ & 13 & 75 & 30 \\
\hline 14 May & 21 & 84 & 46 & $16 \mathrm{Dec}$ & 9 & 75 & 30 \\
\hline 19 May & 13 & 84 & 46 & & & & \\
\hline 24 May & 12 & 84 & 27 & & & & \\
\hline 30 May & 13 & 0 & 0 & & & & \\
\hline 4 Jun & 13 & 84 & 0 & & & & \\
\hline 10 Jun & 12 & 0 & 0 & & & & \\
\hline 17 Jun & 13 & 0 & 0 & & & & \\
\hline Sum & 266 & 666 & 319 & Sum & 198 & 590 & 310 \\
\hline
\end{tabular}

${ }^{\mathrm{a}} \mathrm{WS}$ and AW denote winter-spring season and autumn-winter season, respectively.

${ }^{\mathrm{b}} \mathrm{Nmt}$ and $\mathrm{Nmr}$ denote conventional $\mathrm{N}$ management and $\mathrm{N}$ reduced management, respectively.

\section{WS season:}

$\mathrm{N}$ uptake $=-0.0337 \mathrm{DAT}^{2}+8.2533 \mathrm{DAT}-216.04\left(R^{2}=0.967^{* *}\right)$

AW season:

$\mathrm{N}$ uptake $=-0.0174 \mathrm{DAT}^{2}+4.1953 \mathrm{DAT}-79.94\left(R^{2}=0.972^{* *}\right)$

where DAT denotes days after transplanting.

Furrow irrigation systems were adopted in the greenhouse, based on the conventional schedule. Urea was selected for $\mathrm{N}$ topdressing and was dissolved and flushed into the field with the irrigation water. The details of each irrigation and/or fertilization event are recorded in Tables 1 and 2 . The polyethylene film covering the greenhouse was removed during the summer fallow periods and total amounts of precipitation during the summer growing seasons were $299 \mathrm{~mm}$ in 2005 and $491 \mathrm{~mm}$ in 2006 .

The experiment was a completely randomized block design with three replicates and the size of each replicate plot was $4.8 \mathrm{~m} \times 5.5 \mathrm{~m}$.

\subsection{Nitrogen balance calculation}

$\mathrm{N}$ balance was calculated following Eq. (2) as described by Patil et al (2001).

$\mathrm{N}_{\text {balance }}=\mathrm{N}_{\text {min initial }}+\mathrm{N}_{\text {manure }}+\mathrm{N}_{\text {fer }}-\mathrm{N}_{\text {crop }}-\mathrm{N}_{\text {min harvest }}$

Where:

$\mathrm{N}_{\text {balance }}=\mathrm{N}$ balance

$\mathrm{N}_{\min \text { initial }}=$ Soil $\mathrm{N}_{\min }$ at $0-0.3 \mathrm{~m}$ depth before transplanting

$\mathrm{N}_{\text {manure }}=$ Total $\mathrm{N}$ input from organic manure

$\mathrm{N}_{\text {fer }}=\mathrm{N}$ from applied fertilizer

$\mathrm{N}_{\text {crop }}=$ Total $\mathrm{N}$ uptake in cucumber aboveground parts

$\mathrm{N}_{\text {min harvest }}=$ soil $\mathrm{N}_{\min }$ at $0-0.3 \mathrm{~m}$ depth at harvest

\subsection{Sampling and analysis}

Every 2-3 weeks two plants were taken from each plot to measure dry matter weight and tissue $\mathrm{N}$ concentration. Fresh shoot samples were separated into leaves, stems and fruits and immediately dried for $30 \mathrm{~min}$ at $105{ }^{\circ} \mathrm{C}$, and then dried at $70^{\circ} \mathrm{C}$ to constant weight. The dried shoots were ground to $<1 \mathrm{~mm}$ before determination of total $\mathrm{N}$. A modified Kjeldahl method with salicylic acid was used to analyze total $\mathrm{N}$ in the plant samples. $\mathrm{N}$ uptake was calculated as the product of dry matter and total $\mathrm{N}$ concentration in leaves, stems and fruits.

Six cores were sampled from the top $30 \mathrm{~cm}$ of the soil profile in each plot two or three days before $\mathrm{N}$ side-dressing. The six cores were mixed thoroughly to give a composite sample and passed through a 4-mm sieve. A total of 12-g sub-samples were extracted with $0.01 \mathrm{~mol} \mathrm{~L}^{-1} \mathrm{CaCl}_{2}$ at a ratio of 1:10 (dry soil wt/extractant volume) with shaking for $1 \mathrm{~h}$ and filtration of the extract. The filtrate was analyzed for nitrate and ammonium using a continuous flow autoanalyzer (TRAACS Model 2000) according to Houba et al. (1986). Water in the soil samples was determined gravimetrically to calculate soil $\mathrm{N}_{\min }$ on a dry matter basis. Field bulk density data were used for the conversion of mineral $\mathrm{N}$ in $\mathrm{mg}$ per $\mathrm{kg}$ soil to $\mathrm{kg}$ per hectare.

Soil ( $0.1 \mathrm{~m}$ layer) and air temperatures were recorded at 10 o'clock daily with a geothermometer during the experiment (Fig. 1).

\subsection{Data analysis}

Statistical analysis of the data was performed using analysis of variance and pairs of mean values were compared by least significant difference (LSD) at the 5\% level using the Version 6.12 of the SAS software package (SAS Institute Inc., Cary, NC).

\section{Results}

\subsection{Fruit yields}

Seasonal influences on cumulative fruit yields of cucumber during different growth periods and under different fertilization treatments are summarized in Table 3 . Considering all $\mathrm{N}$ fertilization treatments in 2005 and 2006, average fruit yields in the AW seasons ranged from 33 to $42 \mathrm{tha}^{-1}$ but only $47-53 \%$ of those in the WS seasons. Very low fruit yields of AW season cucumber were obtained in the late growth stages (81-121 DAT in 2005 and 69-116 DAT in 2006), which only accounted for one third of average fruit yield level at similar growth stages of the WS seasons. Seasonal differences in temperatures strongly affected fruit loading. On average, 8 fruits occurred per plant in WS cucumber shoots and this was more than the fruit loading in AW cucumber (5 fruits per plant).

Fertilizer $\mathrm{N}$ significantly promoted some of the cucumber fruit yields during the earlier or later fruit maturity period, except for the earlier stages in the WS and AW seasons of 2005 during which there were relatively high soil $\mathrm{N}$ supply levels. The fruit yields in the four growing seasons showed that $\mathrm{N}$ topdressing in Nmt and Nmr treatments significantly increased fruit yields compared with $\mathrm{Nm} 0$ and NOO treatments. However, there were no significant differences in cucumber fruit yields between $\mathrm{Nmt}$ and $\mathrm{Nmr}$ treatments, either within each season or over all four seasons despite the average $54 \%$ of $\mathrm{N}$ across the four seasons being reduced in the Nmr treatment.

The differences in fruit yields between WS and AW seasons demonstrated that seasonal influences on fruit yield were much higher than the effects of the different fertilization treatments. It appears that low soil $\mathrm{N}$ supply levels in the AW seasons would 

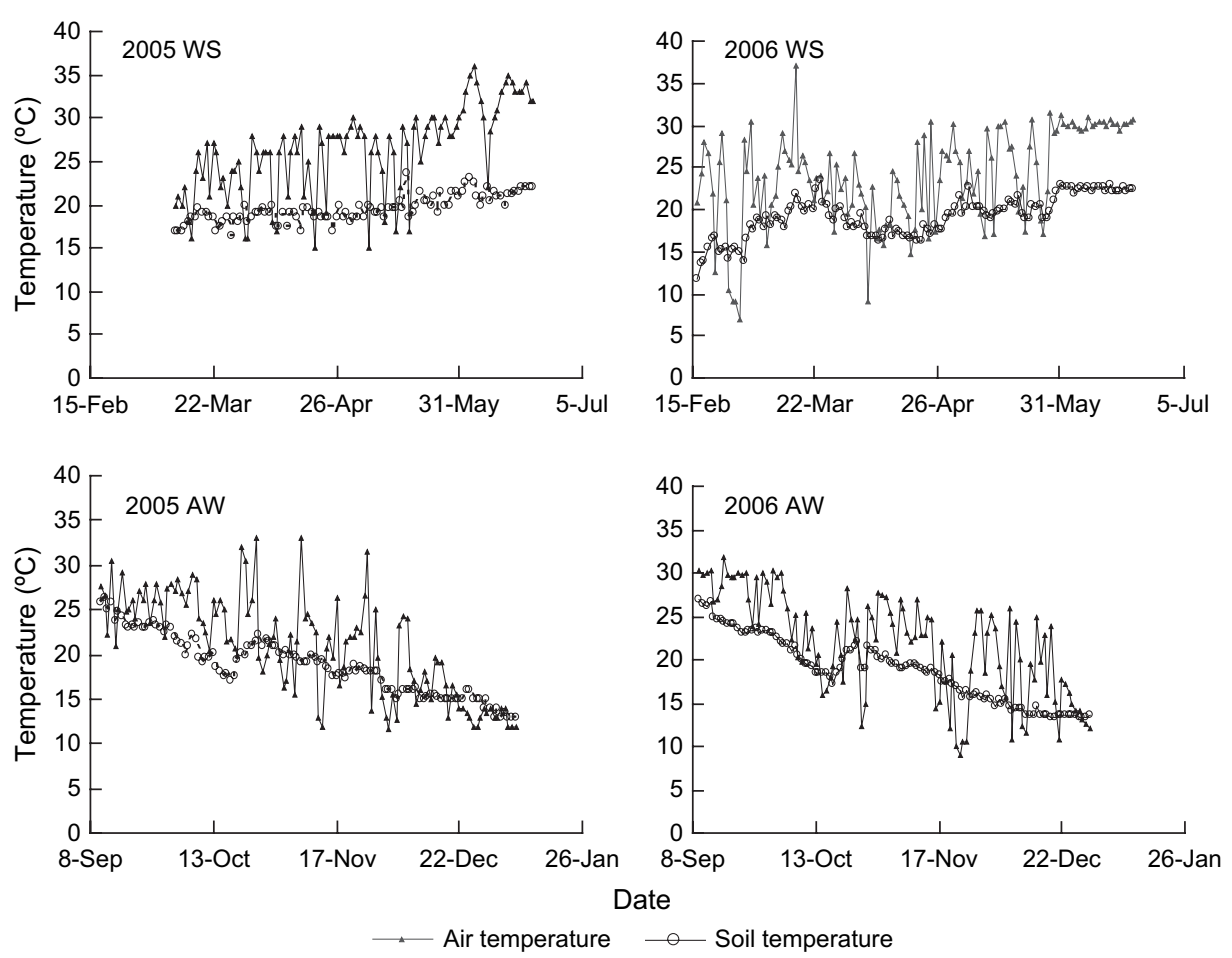

Fig. 1. Daily air and soil temperatures in cucumber greenhouse cropping system in 2005 and 2006 at Changping, Beijing suburbs.

have necessitated higher $\mathrm{N}$ fertilizer inputs to increase fruit yields to levels comparable with the WS seasons.

\subsection{Proportion of dry matter allocation}

Dry weights of cucumber shoots (Table 4) also showed significant differences between WS and AW seasons. Dry weights in the AW seasons decreased by $29-40 \%$ compared to the WS seasons among the different $\mathrm{N}$ treatments in 2005 and 2006. Shoot dry weights of cucumber in the N00 treatment were significantly lower than in the other treatments throughout the experiment.

The proportion of dry matter distributed in the fruits was related to fruit growth rate. Seasonal differences in the proportion of dry matter partitioned to the fruits accounted for $41.2 \%$ and $32.4 \%$ of shoot dry matter yield in the WS and AW seasons, respectively. This indicates that higher proportions of dry matter were maintained in the generative organs in WS seasons compared to AW because of high cumulative temperatures and high fruit loading in the former. The average proportion of dry matter partitioned to the vegetative parts of all fertilization treatments in the WS season was 1.44 times higher than that in AW season, while dry matter partitioned to the fruits in WS seasons was 2.32 times higher than in the AW seasons. Fruit loading (dry weight of fruits) was therefore more sensitive to seasonal temperature differences the growth of the vegetative parts. Nitrogen topdressing in Nmt and Nmr treatments also enhanced the distribution of dry matter to the fruits in comparison with $\mathrm{Nm} 0$ and $\mathrm{N} 00$ treatments but these fertilizer $\mathrm{N}$ effects were smaller than the seasonal effects.

\section{3. $N$ uptake pattern, $N_{\min }$ in root zone and $N$ supply}

Seasonal patterns of $\mathrm{N}$ uptake were similar to dry matter accumulation in all fertilization treatments (Fig. 2). $\mathrm{N}$ uptake by shoots of AW season cucumber decreased by $49-58 \%$ compared to that of WS cucumber across different fertilizer treatments. Due to relatively high soil fertility in 2005 and low temperature in the $\mathrm{AW}$ season there were no significant difference among Nm0, Nmt and Nmr treatments, but they showed significantly higher N uptake than the N00 treatment in 2005. The pattern of change in $\mathrm{N}$ uptake in 2006 was different from that in 2005. Significant differences in N uptake were observed from 4 May to the end of the harvest in the WS season and from 9 October to the end of the harvest in the AW season in 2006. N supply either with organic manure or chemical fertilizer significantly enhanced $\mathrm{N}$ uptake by increasing dry matter yield and plant $\mathrm{N}$ concentration (data not shown). In the AW seasons the difference in $\mathrm{N}$ uptake $\mathrm{N} 00$ and $\mathrm{Nm} 0$ plants was mainly due to dry matter yield while the difference in $\mathrm{N}$ uptake among $\mathrm{Nm} 0$ and $\mathrm{Nmr}$ and $\mathrm{Nmt}$ treatments was mainly due to plant $\mathrm{N}$ concentration. In the WS seasons the differences in $\mathrm{N}$ uptake among $\mathrm{N}$ treatments was dependent on both dry matter yield and plant $\mathrm{N}$ concentrations.

After the first $\mathrm{N}$ topdressing event the soil $\mathrm{N}_{\min }$ contents in root zone of the Nmr treatment remained at around $200 \mathrm{~kg} \mathrm{ha}^{-1}$ in $2005 \mathrm{WS}, 2005 \mathrm{AW}$ and $2006 \mathrm{WS}$ seasons, and $150 \mathrm{~kg} \mathrm{ha}^{-1}$ in $2006 \mathrm{AW}$, respectively, levels which were markedly lower than the Nmt treatment but without any reduction in fruit yield. Organic manure application increased the soil organic $\mathrm{N}$ pool and at transplanting of the 2005 WS growing season excessive organic manure application led to high $\mathrm{N}_{\min }$ in the root zone. 


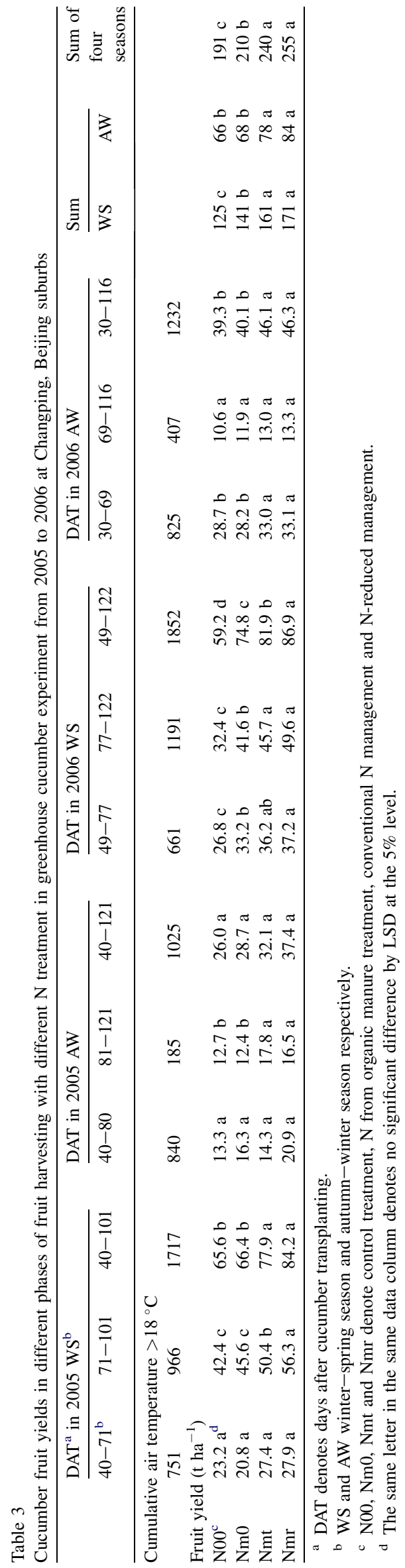

Soil $\mathrm{N}_{\text {min }}$ readily accumulated in the root zone at later growth stages in the AW season but not the WS season because of seasonal differences in cucumber growth rate and irrigation regime under different climatic conditions. After four seasons of cucumber cropping there were no pronounced differences in $\mathrm{N}_{\text {min }}$ content between $\mathrm{Nm0}$ and $\mathrm{N} 00$ treatments, especially in 2006. In contrast to the N00 treatment, higher soil N mineralization increased cucumber dry matter yields and $\mathrm{N}$ uptake in the $\mathrm{Nm} 0$ treatment, but the $\mathrm{N}$ supply in $\mathrm{Nm} 0$ was inadequate to maintain the critical $\mathrm{N}$ concentration in the root zone for the marketable yield to reach that in Nmt and Nmr treatments. Fig. 2 shows that high $\mathrm{N}_{\min }$ residues in the root zone were found in the Nmr treatment at harvest despite a substantial reduction in fertilizer $\mathrm{N}$ application rate and these would be vulnerable to loss the following season.

\section{4. $N$ balance}

Although significant seasonal differences were found in fruit yield, dry matter allocation and $\mathrm{N}$ uptake in the WS and AW seasons in 2005 and 2006, no clear seasonal differences in apparent $\mathrm{N}$ balance in the soil-vegetable system were observed. However, different $\mathrm{N}$ fertilizer treatments had pronounced effects on $\mathrm{N}$ balance (Table 5). A balanced $\mathrm{N}$ recommendation strategy in the $\mathrm{Nmr}$ treatment would have allowed substantial reductions in $\mathrm{N}$ loss by $48,40,47$ and $32 \%$ compared to traditional $\mathrm{N}$ management $(\mathrm{Nmt})$ during the four successive growing seasons. Cucumber $\mathrm{N}$ demand in the AW season was much lower than that in the WS season but the recommended $\mathrm{N}$ rates in the $\mathrm{Nmr}$ treatment did not reflect the seasonal differences observed in our study.

With the Nmr treatment, $\mathrm{N}$ inputs from organic fertilizer accounted for $51,20,17$ and $22 \%$ of the total $\mathrm{N}$ input in the four consecutive growing seasons was and the corresponding values for the Nmr treatment were $36,14,12$ and $14 \%$. In contrast, chemical $\mathrm{N}$ fertilizer inputs in the $\mathrm{Nmt}$ treatment were 2.9-4.5 fold greater than $\mathrm{N}$ removal in the above-ground plant parts over the four growing seasons and the range was only 0.6-2.5 fold in the Nmr treatment (Table 4). Higher ratios of chemical fertilizer $\mathrm{N}$ inputs to $\mathrm{N}$ removal were observed in the AW seasons than in the WS seasons. This indicates a higher $\mathrm{N}$ requirement in the WS seasons and crop growth was more dependent on fertilizer $\mathrm{N}$ inputs in the AW seasons with their lower temperatures.

\section{Discussion}

Significant seasonal differences in fruit yield, dry weight and $\mathrm{N}$ uptake of greenhouse cucumber were found between WS and AW seasons. The cumulative temperature at fruit maturity stage is one of the key factors influencing fruit formation and marketable yield (Darawsheh and Bouranis, 2006). The proportion of dry matter partitioned to the fruit also varied by $9 \%$ between AW and WS seasons. Heuvelink and Buiskool (1995) suggested that dry matter partitioning was not directly affected by temperature, but instead by the indirect effects of rates of development and fruit numbers. 

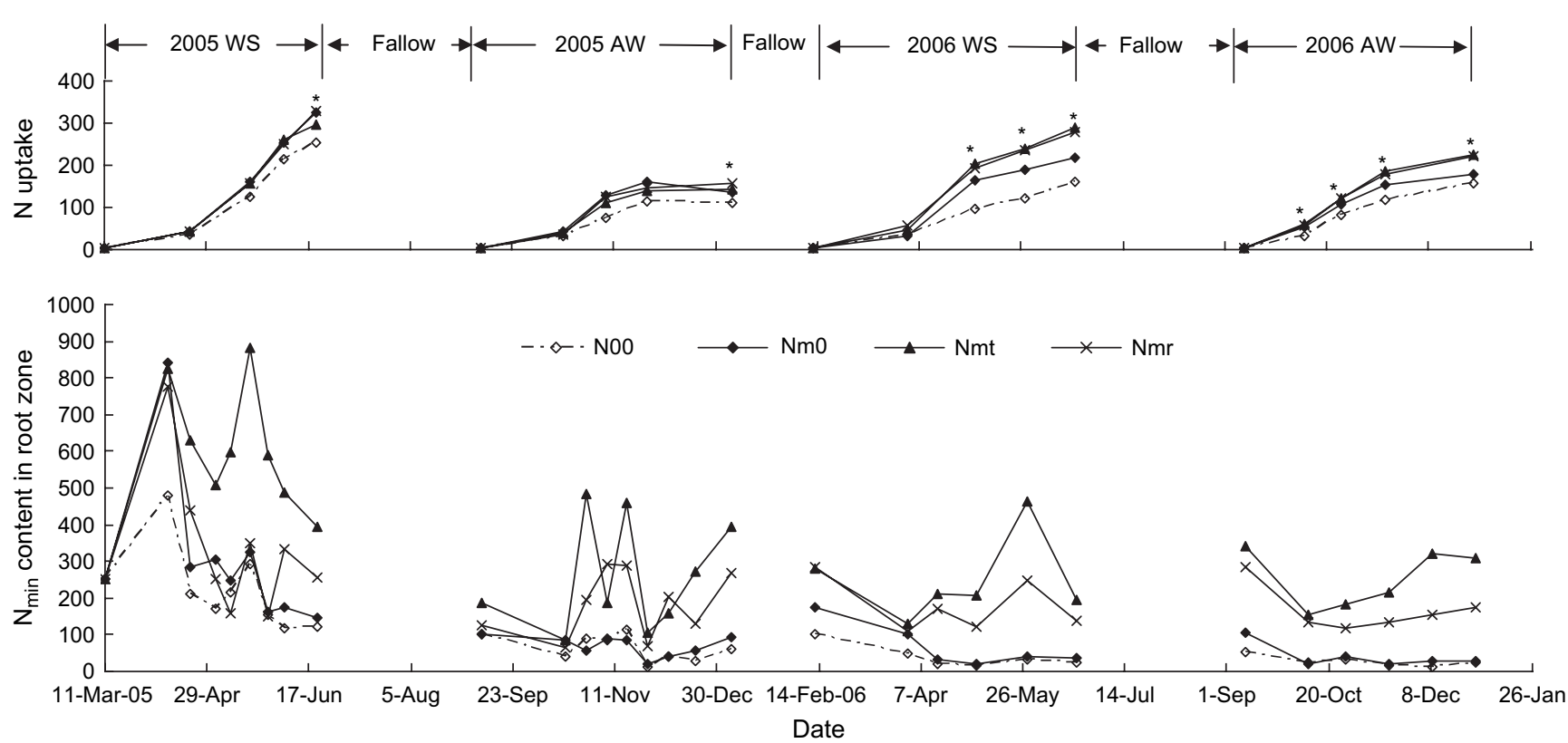

Fig. 2. Seasonal pattern of cucumber $\mathrm{N}$ uptake and $\mathrm{N}_{\min }$ content in root zone with different $\mathrm{N}$ treatments in greenhouse cropping system from 2005 to 2006 at Changping, Beijing suburbs. (Units: $\mathrm{kg} \mathrm{ha}^{-1}$ ). ${ }^{*}$ denotes significant difference in $\mathrm{N}$ uptake on the same sampling date by LSD at the $5 \%$ level.

In addition, partitioning to fruits was affected by fruit loading, thus decreasing the number of fruits per plant and thereby diminishing the proportion of total biomass allocated to the fruits (Heuvelink and Buiskool, 1995; Heuvelink, 1997). According to Lorenz and Maynard (1980), the low temperature limit $\left(>18{ }^{\circ} \mathrm{C}\right)$ for cucumber fruit growth indicates that low temperatures during late maturity may result in small numbers of fruits per plant and inhibit cucumber growth in the AW seasons. Light is also an important factor affecting cucumber fruit yield in the AW season. The intensity of illumination in the AW season is only $54-63 \%$ of that in the WS season in greenhouse cucumber cropping systems in Beijing (Pei, 2002). Hao and Papadopoulos (1999) reported that supplemental lighting promoted plant development and early

Table 4

Dry matter accumulation and proportion of dry matter partitioned to fruits with different $\mathrm{N}$ management in greenhouse cucumber cropping systems in 2005 and 2006 at Changping, near Beijing

\begin{tabular}{|c|c|c|c|c|c|c|c|c|}
\hline & \multicolumn{4}{|c|}{$\begin{array}{l}\text { Dry matter } \\
\text { weight }\left(\mathrm{kg} \mathrm{ha}^{-1}\right)\end{array}$} & \multicolumn{4}{|c|}{$\begin{array}{l}\text { Proportion of dry matter } \\
\text { partitioned to fruits }(\%)\end{array}$} \\
\hline & $05 \mathrm{WS}^{\mathrm{a}}$ & $06 \mathrm{WS}$ & $05 \mathrm{AW}$ & $06 \mathrm{AW}$ & $05 \mathrm{WS}$ & $06 \mathrm{WS}$ & $05 \mathrm{AW}$ & $06 \mathrm{AW}$ \\
\hline $\mathrm{NOO}^{\mathrm{b}}$ & $6193 b^{c}$ & $6991 \mathrm{c}$ & $3989 \mathrm{~b}$ & $4219 \mathrm{~b}$ & 42 & 37 & 28 & 36 \\
\hline $\mathrm{Nm} 0$ & $7889 a$ & $7712 \mathrm{~b}$ & $5047 \mathrm{a}$ & $4841 \mathrm{a}$ & 35 & 41 & 27 & 33 \\
\hline $\mathrm{Nmt}$ & $7252 \mathrm{a}$ & $8470 \mathrm{a}$ & $5082 \mathrm{a}$ & $5092 \mathrm{a}$ & 42 & 44 & 30 & 37 \\
\hline $\mathrm{Nmr}$ & $7918 \mathrm{a}$ & $8538 \mathrm{a}$ & $5424 \mathrm{a}$ & $5117 \mathrm{a}$ & 44 & 45 & 33 & 36 \\
\hline
\end{tabular}

${ }^{\text {a }}$ WS and AW denote winter-spring season and autumn-winter season respectively.

${ }^{b} \mathrm{~N} 00, \mathrm{Nm} 0, \mathrm{Nmt}$ and Nmr denote control treatment, $\mathrm{N}$ from organic manure treatment, conventional $\mathrm{N}$ management and $\mathrm{N}$-reduced management.

c The same letter in the same data column denotes no significant difference by LSD at the $5 \%$ level. marketable yield production, and increased dry matter allocation to the fruits under greenhouse conditions during winter.

In our experiment we also found that inadequate $\mathrm{N}$ status of plant tissues and low temperatures affected sex expression in cucumber. $\mathrm{N}$ topdressing significantly enhanced the allocation of dry matter to the fruits and then increasing the fruit yield by direct dry matter establishment and translocation from the vegetative parts during the fruit maturation stage. The maximum proportion of dry matter partitioned to the fruits was investigated in the Nmr treatment in most of the growing seasons.

Excessive $\mathrm{N}$ in the soil-plant system is associated with environmental hazards (Crews and Peoples, 2005; Olfs et al., 2005). It is necessary to take account of the seasonal patterns of $\mathrm{N}$ uptake for effective $\mathrm{N}$ recommendations in greenhouses without supplementary heating or illumination on the North China Plain. Synchronizing cucumber $\mathrm{N}$ demand with critical nutrient supply at different growth stages is the key objective to solve the conflict between high yields and environmental protection. In the 2005 WS season excessive N supply, which accumulated as a result of traditional organic manure application in the preceding growing period, resulted in 'luxury' $\mathrm{N}$ uptake and allowed a marked reduction in $\mathrm{N}$ topdressing with balanced $\mathrm{N}$ management in the Nmr treatment. In subsequent seasons the recommended $\mathrm{N}$ application rate increased as $\mathrm{N}$ supplied by organic manure declined. Lower $\mathrm{N}$ uptake by cucumber was observed in autumn-winter compared with winter-summer because low root temperatures directly affected $\mathrm{N}$ absorption and translocation (Frota and Tucker, 1972; Papadopoulos and Tiessen, 1987). However, clear seasonal differences were not observed in the total recommended $\mathrm{N}$ rate in spite of large seasonal differences in $\mathrm{N}$ uptake of cucumber shoots. $50 \%$ and $35 \%$ of fertilizer $\mathrm{N}$ was applied during the late fruit maturation periods $(81-121$ DAT in the 2005 AW season and 69-116 DAT in the 2006 AW 
season), in order to maintain adequate $\mathrm{N}_{\min }$ in the rooting zone. However, the appropriate $\mathrm{N}$ input calculated by Eq. (1) was not correlated with high yield during this period which would be one of the key factors resulting in high fertilizer $\mathrm{N}$ inputs in the AW season. Restricted soil organic $\mathrm{N}$ mineralization at low temperatures might be an additional explanation for the high $\mathrm{N}$ fertilizer rate required to satisfy the relatively low $\mathrm{N}$ demand of cucumber in the AW season. In addition to the $\mathrm{N}$ uptake pattern, the irrigation regime during the different seasons determined soil $\mathrm{N}_{\text {min }}$ levels in the rooting zone and had a large effect on $\mathrm{N}$ fertilizer recommendations. Low irrigation rates were applied during the later fruiting period in the AW season in contrast to the WS season, and this would have reduced the risk of nitrate leaching out of the root zone and therefore unavailable for crop growth during irrigation (Nakamura et al., 2004; Tarkalson et al., 2006). $\mathrm{N}$ supply strategies during the AW seasons are therefore distinct from those in the WS seasons. In our experiment it appeared that high $\mathrm{N}$ inputs from fertilizer were necessary over the whole fruit maturation period because of the high rates of plant $\mathrm{N}$ uptake and irrigation in the WS season. However, the situation was different in the late fruiting period of the AW season due to the low $\mathrm{N}$ uptake rate and lower irrigation rate, especially in 2006 (Tables 1 and 2, Fig. 2). According to the fruit yield results in the two AW seasons, fertilizer $\mathrm{N}$ supply could be lowered by reducing the soil $\mathrm{N}_{\min }$ safety margin. Further studies are necessary to establish the optimum proportions of basal $\mathrm{N}$ fertilizer and $\mathrm{N}$ topdressing at different growth stages according to variations in seasonal conditions.

Reduced $\mathrm{N}$ management (Nmr) efficiently reduced $\mathrm{N}$ losses by $47 \%$ and $36 \%$ in WS seasons and WA seasons, respectively. $\mathrm{N}$ losses in the Nmr treatment readily occurred in the AW seasons because of low $\mathrm{N}$ uptake but with the same $\mathrm{N}$ supply as in the WS seasons. Zhu et al. (2005) reported nitrate leaching was the main route of $\mathrm{N}$ loss and accounted for the nearly one-third reduction in $\mathrm{N}\left(600 \mathrm{~kg} \mathrm{~N} \mathrm{ha}^{-1}\right)$ application rate that was possible instead of the conventional practice $\left(1800 \mathrm{~kg} \mathrm{~N} \mathrm{ha}^{-1}\right)$ in hot pepper greenhouse cropping system in Shouguang, Shandong province. Thus, despite the use of best management practices for $\mathrm{N}$ application rate and timing, significant losses of nitratenitrogen in drainage discharge continue to occur from cropping systems (Strock et al., 2004). In our experiment at least $386 \mathrm{~kg} \mathrm{~N} \mathrm{ha}^{-1}$ (not including $\mathrm{N}$ mineralization) per season was lost from the plant-soil system. $\mathrm{N}$ leaching from soil mineralization was likely to be considerable due to higher $\mathrm{N}$ release from non-avaliable forms of N, most likely as a result of increased mineralization of crop residues and recently formed soil organic matter (Stevens et al., 2005). It is therefore necessary to include $\mathrm{N}$ mineralization as a key component in the calculation of $\mathrm{N}$ recommendations.

Some of the vulnerable $\mathrm{N}$ in the leaching zone is difficult to control in greenhouse vegetable production. Analysis of soil $\mathrm{N}_{\text {min }}$ showed that large amounts of $\mathrm{N}$ from chicken manure and soil $\mathrm{N}_{\min }$ residues were leached before fruit maturity among all treatments in both the WS and AW seasons. Frequent irrigation, accounting for $39 \%$ of the total irrigation rate, led to high rates of residual $\mathrm{N}_{\min }$ leaching out of the root zone during crop establishment when there were low plant $\mathrm{N}$ uptake rates 
and shallow root systems. $\mathrm{N}$ leaching during crop establishment accounted for over $50 \%$ of total $\mathrm{N}$ leaching in tomato cropping systems with drip-irrigation in Spain (Vázquez et al., 2006). Moreover, the highest emission rates of $\mathrm{N}_{2} \mathrm{O}$, representing $66.5 \%$ of the cumulative fluxes were measured by $\mathrm{He}$ et al. (2007) from transplanting to the first $\mathrm{N}$ topdressing with four events of irrigation in greenhouse tomato cropping systems in Shouguang. In addition, $\mathrm{N}$ losses outside the growing season might appear to be completely out of the grower's control. At typical intensive precipitation in the summer season on the North China Plain (He et al., 2003), large $\mathrm{N}_{\min }$ residues in the soil profile after the WS season harvest were vulnerable to leaching. Ju et al. (2007) demonstrated the high risk of nitrate leaching in the summer season and suggested that deep-rooted crops such as maize could be used as catch crop to intercept soil nitrate deep in the soil profile to control nitrate leaching. Integrated $\mathrm{N}$ management with catch crops is therefore necessary to optimize $\mathrm{N}$ uptake by roots during fallow periods and maintain low $\mathrm{N}_{\text {min }}$ residues at transplanting to protect the environment from pollution in intensive greenhouse cropping systems.

\section{Conclusions}

Seasonal differences profoundly affected cucumber fruit yields and the cumulative patterns of dry matter weight and $\mathrm{N}$ uptake were investigated in WS and AW seasons. N supply and monitoring of environmental conditions should aim to balance the distribution of assimilates between fruits and vegetative parts. $\mathrm{N}$ recommendations in the $\mathrm{Nmr}$ treatment with low rates of $\mathrm{N}$ over four growing seasons was the optimum strategy for cucumber production and protected the environment by controlling $\mathrm{N}$ leaching losses. It is therefore necessary to synchronize $\mathrm{N}$ recommendations with seasonal differences in crop $\mathrm{N}$ demand with critical nutrient supply at different growth stages in order to minimize $\mathrm{N}$ losses to the environment.

\section{Acknowledgments}

We are grateful to the National Natural Science Foundation of China (Project 30671236) and Key Projects of the Chinese Ministry of Agriculture (2006-G60) for financial support.

\section{References}

Breschini, S.J., Hartz, T.K., 2002. Presidedress soil nitrate testing reduces nitrogen fertilizer use and nitrate leaching hazard in lettuce production. HortScience 37, 1061-1064.

Cabrera, M.L., Chiang, S.C., 1994. Water content effect on denitrification and ammonia volatilization in poultry litter. Soil Science Society of America Journal 57, 811-816.

Cabrera, M.L., Chiang, S.C., Merka, W.C., Thompson, S.A., Pancorbo, O.C., 1993. Nitrogen transformations in surface-applied poultry litter: effect of litter physical characteristics. Soil Science Society of America Journal $57,1519-1525$.

Chen, Q., Zhang, X.S., Zhang, H.Y., Christie, P., Li, X.L., Horlacher, D., Liebig, H.P., 2004. Evaluation of current fertilizer practice and soil fertility in vegetable production in the Beijing region. Nutrient Cycling in Agroecosystems $69,51-58$.
Crews, T.E., Peoples, M.B., 2005. Can the synchrony of nitrogen supply and crop demand be improved in legume and fertilizer-based agroecosystems? A review. Nutrient Cycling in Agroecosystems 72, 101-120.

Darawsheh, M.K., Bouranis, D.L., 2006. Season-dependent fruit loading: effect on dry mass, water, and nitrogen allocation in tomato plants. Journal of Plant Nutrition 29, 347-359.

Fink, M., Scharpf, H.C., 1993. N-EXPERT: a decision support system for vegetable fertilization in the field. Acta Horticulturae 339, 67-74.

Fox, R.H., Piekielek, W.P., MacNeal, K.E., 1996. Estimating ammonia volatilization losses from urea fertilizers using a simplified micrometeorological sampler. Soil Science Society of America Journal 60, 591-601.

Frota, J., Tucker, T.C., 1972. Temperature influence on ammonium and nitrate absorption by lettuce. Proceedings of the Soil Science Society of America $36,97-100$.

Gollany, H.T., Molina, J.E., Clapp, C.E., Allmaras, R.R., Layese, M.F., Baker, J.M., Cheng, H.H., 2004. Nitrogen leaching and denitrification in continuous corn as related to residue management and nitrogen fertilization. Environmental Management 33 (Suppl. 1), S289-S298.

Hao, X.M., Papadopoulos, A.P., 1999. Effects of supplemental lighting and cover materials on growth, photosynthesis, biomass partitioning, early yield and quality of greenhouse cucumber. Scientia Horticulturae 80, 1-18.

Hartz, T.K., Bendixen, W.E., Wierdsma, L., 2000. The value of presidedress soil nitrate testing as a nitrogen management tool in irrigated vegetable production. HortScience 35, 651-656.

He, Y.H., Cheng, Z.Q., Guan, C.H., 2003. Relationship between long-term changes of summer rainfall in North China and sea surface temperature over South China sea. Journal of Tropical Oceanography 22 (1), 1-8 (In Chinese with English summary).

He, F.F., Chen, Q., Jiang, R.F., Chen, X.P., Zhang, F.S., 2007. Yield and nitrogen balance of greenhouse tomato (Lycopersicum esculentum Mill.) with conventional and site-specific nitrogen management in Northern China. Nutrient Cycling in Agroecosystems 77, 1-14.

Heckman, J.R., Morris, T., Sims, J.H., Sieszka, J.B., Krogmann, U., Nitzsche, P., Asheley, R., 2002. Pre-sidedress soil nitrate test is effective for fall cabbage. HortScience 37, 113-117.

Heuvelink, E., 1997. Effect of fruit load on dry matter partitioning in tomato. Scientia Horticulturae 69, 51-59.

Heuvelink, E., Buiskool, R.P.M., 1995. Influence of sink-source interaction on dry matter production in tomato. Annals of Botany 75, 381-389.

Houba, V.J.G., Novozamsky, I., Huybregts, A.W.M., 1986. Comparison of soil extractions by $0.01 \mathrm{M} \mathrm{CaCl}_{2}$, by EUF and some conventional extraction procedures. Plant and Soil 96, 433-437.

Ju, X.T., Kou, C.L., Zhang, F.S., Christie, P., 2006. Nitrogen balance and groundwater nitrate contamination: comparison among three intensive cropping systems on the North China Plain. Environmental Pollution $143,117-125$.

Ju, X.T., Gao, Q., Christie, P., Zhang, F.S., 2007. Interception of residual nitrate from a calcareous alluvial soil profile on the North China Plain by deep-rooted crops: a ${ }^{15} \mathrm{~N}$ tracer study. Environmental Pollution 146, 534-542.

Kotsiras, A., Olympios, C.M., Drosopoulos, J., Passam, H.C., 2002. Effects of nitrogen form and concentration on the distribution of ions within cucumber fruits. Scientia Horticulturae 95, 175-183.

Krusekopf, H.H., Mitchell, J.P., Hartz, T.K., May, D.M., Miyao, E.M., Cahn, M.D., 2002. Pre-sidedress soil nitrate testing identifies processing tomato fields not requiring sidedress $\mathrm{N}$ fertilizer. HortScience 37, $520-524$.

Lorenz, O.A., Maynard, D.N., 1980. Knott's Handbook for Vegetable Growers, second ed. J. Wiley, New York, 388 pp.

Nakamura, K., Harter, T., Hirono, Y., Horino, H., Mitsuno, T., 2004. Assessment of root zone nitrogen leaching as affected by irrigation and nutrient management practices. Vadose Zone Journal 3, 1353-1366.

Olfs, H.W., Blankenau, K., Brentrup, F., Jasper, J., Link, A., Lammel, J., 2005. Soil-and plant-based nitrogen-fertilizer recommendations in arable farming. Journal of Plant Nutrition and Soil Science 168, 414-431.

Papadopoulos, A.P., Tiessen, H., 1987. Root and air temperature effects on elemental composition of tomato. Journal of the American Society for Horticultural Science 112, 988-993. 
Patil, S.K., Singh, U., Singh, V.P., Mishra, V.N., Das, R.O., Henao, J., 2001. Nitrogen dynamics and crop growth on an Alfisol and Vertisol under a directseeded rained lowland rice-based system. Field Crops Research 70, 185-199.

Pei, X.B., 2002. Studies on Regularity of Water and Solute Transfer of Cucumber Growing in Solar Greenhouse. PhD Dissertation, China Agricultural University, Beijing, China, 79 pp (In Chinese with English summary).

Ramos, C., Agut, A., Lidon, A.L., 2002. Nitrate leaching in important crops of the Valencian Community region (Spain). Environmental Pollution 118, 215-223.

Stevens, W.B., Hoeft, R.G., Mulvaney, R.L., 2005. Fate of nitrogen in a longterm Nitrogen rate study: I. Interactions with soil nitrogen. Agronomy Journal 97, 1037-1045.

Strock, J.S., Porter, P.M., Russelle, M.P., 2004. Cover cropping to reduce nitrate loss through subsurface drainage in the Northern U.S. corn belt. Journal of Environmental Quality 33 (3), 1010-1016.

Tarkalson, D.D., Payero, J.O., Ensley, S.M., Shapiro, C.A., 2006. Nitrate accumulation and movement under deficit irrigation in soil receiving cattle manure and commercial fertilizer. Agricultural Water Management 85, 201-210

Tremblay, N., Scharpf, H.C., Weier, U., Laurence, H., Owen, J., 2001. Nitrogen management in field vegetables. A guide to efficient fertilization. Agriculture and Agri-Food, Canada. pp. 65. <http://sci.agr.ca/stjean/publication/ bulletin/nitrogen-azote_e.htm $>$.

Vázquez, N., Pardo, A., Suso, M.L., Quemada, M., 2006. Drainage and nitrate leaching under processing tomato growth with drip irrigation and plastic mulching. Agriculture. Ecosystems and Environment 112, 313323.

Zhang, W.L., Tian, Z.X., Zhang, N., Li, X.Q., 1996. Nitrate pollution of groundwater in northern China. Agriculture. Ecosystems and Environment 59, 223-231.

Zhu, J.H., Li, X.L., Christie, P., Li, J.L., 2005. Environmental implications of low nitrogen use efficiency in excessively fertilized hot pepper (Capsicum frutescens L.) cropping systems. Agriculture. Ecosystems and Environment $111,70-80$. 